\title{
Development of Learning by E-Learning System: A Case of Mahamakut Buddhist University, Mahavajiralongkorn Rajaviyalaya Campus
}

\author{
Phramaha Paijit Uttamadhammo (Sakhong) ) $^{1, *}$ \& Phrakrusutheejariyawattana ${ }^{2}$ \\ ${ }^{1}$ Mahamakut Buddhist University, Mahavajiralongkorn Rajaviyalaya Campus, Ayutthaya Province, Thailand \\ ${ }^{2}$ Mahamakut Buddhist University, Isan Campus, Khon Kaen Province, Thailand \\ *Correspondence: Mahamakut Buddhist University, Mahavajiralongkorn Rajaviyalaya Campus, Ayutthaya Province, \\ Thailand. Tel: 66-82-542-8481. E-mail: paijitsakong@gmail.com
}

Received: May 14, 2021

doi:10.5430/wje.v11n3p47
Accepted: June 15, $2021 \quad$ Online Published: June 12, 2021

URL: https://doi.org/10.5430/wje.v11n3p47

\begin{abstract}
This research aimed to develop learning by e-learning system in Mahamakut Buddhist University, Mahavajiralongkorn Rajaviyalaya Campus. The method used in this study was Participatory Action Research that consisted of two cycles of planning, practice, observation, and reflection during two semesters in the academic year 2020. Twenty-one teachers and forty students were voluntarily involved with the desired development and participated in this research. The three expectations from the development outcomes were: 1) the improvement under the identified indicators, 2) the researcher, the research participants, and the campus learned from practice, and 3) knowledge gained from practice will benefit continuous improvement in the future. The research findings illustrated three following aspects. Firstly, in both Cycles 1 and 2, the means of post-practice evaluations were higher than the means of pre-practice evaluations in the following programs; e-learning system development, meditation practice learning development, and teacher's skill enhancement for creating online media. Secondly, the researcher, the research participants, and the campus learned the following common aspects: an awareness of the importance of participation, being an all-the-time learner, and transcribing lessons from practice which was previously often neglected. Finally, the knowledge gained correlates with Kurt Lewin's Force-Field Analysis which consists of the following concepts: 1) Expected change, 2) Driving factors for change, 3) Resistance to change and 4) Overcoming resistance. Each component defines a set of thoughts and beliefs that Mahamakut Buddhist University, Mahavajiralongkorn Rajaviyalaya Campus, will implement as a basis for reviewing and strengthening an additional set of ideas and beliefs.
\end{abstract}

Keywords: develop learning, e-learning system, participatory action research

\section{Introduction}

\subsection{Introduce the Problem}

People get involved with the internet in current world society. The educational system has evolved into an online system or a network. The students can simply access the information system by themselves and from any place with a device like a computer connected to the Internet. Computers come in various configurations, from a stationary PC to a portable notebook and a Palm Pilot, a wireless mobile system that allows students to learn anytime and anywhere (Meejoe, 2015; Alshehri \& Cumming, 2020). Moreover, Seanrin (2013) stated that e-learning has four primary characteristics: 1) Anywhere, Anytime, and Anybody, which means learners can be anyone and can access from anyplace. 2) Multimedia is the medium presented on the web. It consists of text, slides, and animation. 3) It is also Non-Linear, i.e., students can choose to study any subject they need, and 4) Interactive with the ability of web documents with links will surely make the content automatically interact with users.

In this era, both teachers and curriculum need to be adjustable, and we should learn new things to make Thailand's higher education survive. Will not survive. Nowadays, we must teach New Media, Social Media, Cross-Posting, Digitization, and Digital Transformation (Sakworawit, 2019). Therefore, the present era is a step into the age that the learners learn by their wisdom. E-learning has a convenient key feature for learner-centered learning, i.e., it uses a universal language in which the learner can communicate with the teacher personally. It is a study that helps learners 
learn to help themselves in certain situations properly. It links to the content, lessons, and time that allows them to solve problems independently. They can also skip lessons that do not meet their needs. They can connect with innovative media and various learning activities to obtain both knowledge and experience. (Casey, 2016)

The researcher had studied the importance of e-learning learning from several scholars' perspectives: Aei (2012), Banthita Blog (2017), Charoenkong (2014), Choojai (2013), Hanımoğlu (2018), Insa-ard (2018), Laohajaratsang (2008), Pahe (2017), Petsringern (2016), Sitthirit (2015), and Supradit (2015). The importance of learning by e-learning can be summarized in 10 points as follows. 1) Anywhere, Anytime, 2) Multimedia, 3) Non-linear, 4) Interactive, 5) Standalone Courses, 6) Learning Games and Simulations, 7) Mobile Learning, 8) Multimedia, 9) Open System, and 10) Synchronous Communication and Asynchronous Communication. The learning development process by e-learning system can be described as follows: Lesson Analysis, Lessons Design, Lessons Development, Lessons Implementation, and Achievement Evaluation. This is consistent with the fundamental principles of teaching and learning design widely used and known as the ADDIE Model, consisting of 5 stages: Analysis, Design, Development, Implementation, and Evaluation (Chawangpan, n.d.).

Mahamakut Buddhist University, Mahavajiralongkorn Rajaviyalaya Campus is located in Phra Nakhon Sri Ayutthaya Province. It is an autonomous educational institution for tertiary education under the Ministry of Higher Education, Science, Research, and Innovation. One of the central policies is to employ information and communication technology as a base in learning activities by focusing on using e-learning systems to support the teaching and learning of the campus in conjunction with regular teaching and learning. However, the teaching and learning management of the campus is currently unable to implement e-learning systems in teaching and learning as outlined in the strategic plan because the e-learning lesson has been under the development process and the full implementation of a learning management system or LMS (Learning Management System) is not available. (Mahamakut Buddhist University, Mahavajiralongkorn Rajaviyalaya Campus, 2019)

As a lecturer at this campus, the researcher was aware of being part of the university's policy response and wanted to enhance teaching and learning management following the university's educational quality assurance standards. Therefore, he needed to develop his professional learning society. In order to step into a learning society in which students can learn what they are interested in at any time and from all locations, learning management needs to be more flexible and allow a variety of forms of learning. The forms can be whether Computer Assisted Instruction, E-Learning, Distance Learning, or many others. This is based on the belief that the present students' potential and campus technology can facilitate learning without boundaries. The researcher believed in the phrase, "Adjust learning and change teaching, "so the E-learning system must particularly transform. The research methodology in this study is Participatory Action Research (PAR). PAR is bottom-up research in which the researcher and the research participants are involved in working in a cooperative and equal manner. The researcher changes the role from being passive to active or participant. The research method is altered from "on them" to "by them or for them" based on the process of Planning, Acting, Observing, and Reflecting in a spiral cycle movement with infinitely continuous operation. The focus is on the expected sustainable change caused by the commitment and participatory role at all stages. The details will be discussed below.

\subsection{Research Objectives}

This research aimed to develop learning by e-learning system in Mahamakut Buddhist University, Mahavajiralongkorn Rajaviyalaya Campus, using Participatory Action Research methods. The nature of this research was characterized by the implementation of an endless spiral cycle of planning, practice, observation, and reflection. Due to the length of the semesters, the researcher had to set up 2 operational cycles in 2 semesters of the academic year 2020 (June 1, 2020 to March 31, 2021). The research participants were 21 teachers from different undergraduate programs and 40 targeted students. The three expectations from the development outcomes were: (1) the improvement under the identified indicators, which can be seen in the comparison of 3 phases: pre-practice, post-practice of Cycles 1 and 2, (2) the researcher, the research participants, and the campus learned from practice and (3) the body of knowledge, which had been obtained from the practice as a foundation theory in Mahamakut Buddhist University, Mahavajiralongkorn Rajaviyalaya Campus context.

\subsection{Review of Related Literature}

Understanding the theoretical concepts of E-learning System Learning development in Participatory Action Research is essential because the researcher must be knowledgeable and theoretical sensitive in the area that the study aims to develop. Therefore, theories can be applied to strengthen the thinking and practice of the research participants effectively. According to the idea that says, "Practice without theory is like a blind person. He cannot go any further, but he can only walk around the old corner. ", the researcher, therefore, studied the theoretical concepts of E-Learning 
System Learning from various sources, i.e., Aei (2012), Banthitablog (2017), Charoenkong (2014), Choojai (2013), Hanımoğlu (2018), Information Technology Service Center (n.d.), Insa-ard (2018), Laohajaratsang (2008), Pahe (2017), Petsringern (2016), Sitthirit (2015), and Supradit (2015). This study discusses three primary sources as described below.

Sitthirit (2015) mentioned that e-learning is teaching in any form that is broadcasting content via electronic media, whether Web-Based Learning, Online Learning, Distance Learning via satellite or online video lessons, etc. He also identified five essential characteristics of E-learning: 1) Anywhere, Anytime, 2) Multimedia, 3) Non-linear, 4) Interaction, and 5) Immediate Response. Moreover, he included the four main elements of E-Learning as they are 1) Content, 2) Learning Management System, 3) Modes of Communication, and 4) Exercise/Test. In addition, he stated that the levels of E-learning media are 1) Online Text, 2) Low-Cost Interactive Online Course, and 3) High-Quality Online Course. Lastly, he described three levels of E-Learning implementation: 1) Supplementary, 2) Complementary, and 3) Comprehensive Replacement.

Charoenkong (2014) mentioned that e-learning is any learning which transmits content via electronic devices, whether it is a computer, internet, intranet, extranet, TV signal, and satellite signal. The content information may be in the familiar forms of learning, which are 1) Online Text, 2) Low-Cost Interactive Online Course, and 3) High-Quality Online Course. He also mentioned three levels of E-Learning implementation: 1) Supplementary, 2) Complementary, and 3) Comprehensive Replacement. Moreover, he identified six essential outstanding characteristics of E-learning: 1) Multimedia, 2) Open System, 3) Interaction, 4) Synchronous Communication, 5) Human Driven, and 6) Keep Log. However, he concluded that E-Learning possesses some limitations, especially in the following aspects: Human \& Machine, System and Teacher \& Learner.

Pahe (2017) described that every type of distance education, whether it is radio, television, or internet, shares this common characteristics: 1) Anywhere, Anytime, 2) Multimedia, 3) Non-Linear, and 4) Interaction. Their components are 1) an electronic lesson, 2) a knowledge management system, 3) communication, and 4) an evaluation of learning results. He also mentioned that the learning forms are1) Standalone Courses, 2) Learning Games and Simulations, 3) Mobile Learning, 4) Social Learning, and 5) Virtual-classroom Courses.

The researcher summarized the development process of e-learning media from the above theoretical perspectives as follows. 1) Analysis It is the stage of e-courseware analysis which is also the first instructional design process. This step includes all e-learning components analysis, i.e., lesson contents, students, learning objectives, equipment, tools, and technology used in teaching and learning. 2) Design It is the process of designing electronic lessons. This step includes the results of the analysis. They are in the form of a draft of distance learning. 3) Development It is the development of electronic lessons. The process includes the production of the designed document as the development of e-learning materials. It starts from writing a storyboard based on the design document of the verified content. Storyboard writing is a description of an instructional screen that shows what learners see, hear, or interact with online lessons on each page. 4) Implementation This step is part of the electronic lesson implementation. 5) Evaluation It is a procedure for assessing the achievement of e-learning classes. At this stage, there is a committee to evaluate the results. Questionnaires are used to assess students' satisfaction. It also includes quizzes that measure their learning results.

\section{Method}

There are various scholarly views related to Participatory Action Research (PAR). These concepts share some standard features and express some differences. The researcher adopted the concepts created by Sanrattana (2018), which analyzed from the studies of Arhar, Holly, \& Kasten (2001), Carr \& Kemmis (1992), Coghlan \& Brannick (2007), Creswell (2008), James, Milenkiewicz, \& Bucknam (2008), Jantasuriyawong (1985), Kaewthep (1989), Kemmis \& McTaggart (1992), McTaggart (1991), McTaggart (2010), and Mills (2007) The essential principle of PAR is it is bottom-up research in which the researcher participated in the research with the research participants in a collaborative and equal manner. The researcher changes the role from being passive to active or participant. The research method is altered from "on them" to "by them or for them" based on the process of Planning, Acting, Observing, and Reflecting in a spiral cycle movement with infinitely continuous operation. The focus is on the expected sustainable change caused by the commitment and participatory role at all stages.

\subsection{Research Process}

Sustainable development is the aim of PAR. The nature of this research was characterized by the implementation of an endless spiral cycle of planning, practice, observation, and reflection. Due to the length of the semesters, the researcher had to set up 2 operational cycles in 2 semesters of the academic year 2020, which started from June 1, 2020 and ended 
on March 31, 2021. Each cycle and process was operated as follows.

\subsubsection{Cycle 1}

Step 1 Preparation. This step consisted of 3 activities as described below.

1) The researcher clarified the research outline to the research participants to ensure their perception and understanding of the content and method of the research. Their understanding helped them decide to participate in the research voluntarily and willingly according to the code of conduct that said, "The researcher must demonstrate the nature of the research process from the outset including providing suggestions and benefits to the research participants."

2) The research participants explained the research techniques that will be used to the research participants, such as planning techniques and planning implementation, observation and recording techniques, brainstorming techniques and lessons learned, and techniques for creating research tools.

3) Lesson learned process was conducted to obtain the following information: 1) performance results, 2) defects or obstacles, 3) observations, comments or suggestions, 4) learning from practice that occurred with the researcher, the research participants and agencies and knowledge gained from practice that arises in this process.

Step 2 Planning. This step consisted of 4 activities as follows:

1) The researcher conducted the brainstorming process based on basic knowledge and experience by asking questions, "How to develop the E-Learning system Mahamakut Buddhist University, Mahavajiralongkorn Rajaviyalaya Campus according to your existing knowledge and experience? What development approaches should be developed and how? ". Based on the principle that said, "The research participants are a stream of experiences with the knowledge and experience accumulated. They are not empty glass, but they have the potential and knowledge. "

2) The researcher presented the theoretical development path to the research participants, "What theoretical views do you want to suggest in order to develop the E-Learning system Mahamakut Buddhist University, Mahavajiralongkorn Rajaviyalaya Campus? ". It was based on the principle that said the researcher is an academic stream with theoretical knowledge and sensitivity in matters to be developed and to create positive attitudes to the research participants that theory and practice go hand in hand. They are not a parallel that never converges.

3) The researcher conducted brainstorming to converge streams of experience and academics to combine the development path determined by the research participants and the development trend from the theoretical point of view presented by the researcher. It was based on the principle that said, "Practice without theory is like a blind person. He cannot go any far, only walks around the old corner. " The result of this activity was an action plan.

4) Lesson learned process.

Step 3 Acting. This step aimed to achieve the results of the action plan set out in step 2. It was based on the principle of "Focus on change and actions to achieve results." It consisted of 4 activities as follows:

1) Preparation of achievement evaluation forms for 3 phases: pre-practice, post-practice in cycle 1, and cycle 2 ,

2) Evaluation of Current Condition (pre-practice in Cycle 1),

3) Implementation of the jointed action plan defined in No. 2,

4) Lesson learned process.

Step 4 Observing. This step used different types of research tools to collect information on the results of the operations at this stage.

Step 5 Reflecting. The researchers used Kurt Lewin's Force-Field Analysis conceptual framework (Lunenburg \& Ornstein, 2000). The analysis covered the following aspects: a) what are the current conditions? b) what are the desired conditions?; c) what is the force for change? d) what are resistances to change?, and e) what are suggestions to increase the force and to reduce the force resistance? The findings were used for the force improvement in Cycle 2 operation.

\subsubsection{Cycle 2}

Step 6 Planning. It consisted of 2 activities: 1) The researcher and the research participants jointly evaluated and created a new action plan after the revision of performance results from the cycle and 2) conducted the lesson transcription.

Step 7 Acting. It consisted of two activities: 1) implementing the specified action plan and 2) removing lessons.

Step 8 Observing. It was similar to Step 4, using different types of research tools to collect information on the results of the operations at this stage. 
Step 9 Reflecting. It adopted Kurt Lewin's concept of Force-Field Analysis which was similar to Step 5.

Step 10 Summarizing the results of the performance in Cycle 1 and Cycle2. It was implementing observations, interviews, audits, notes, assessments, and lessons learned from each step, including the results in step 5 and step 9. The researcher and the research participants met in the seminar to conclude the research results according to the research objectives set.

\subsection{Instruments}

The researcher set the research tools according to the Mills conceptual framework (2007), which was classified into four groups: 1) Observation, 2) In-depth Interview and group interviews, 3) Examining / Record forms such as Journal, Maps, Audiotapes and Videotapes, Artifacts, Field Notes and 4) Evaluation form for the achievement of development.

\subsection{Data Collection}

The researchers and the research participants played a role in collecting the data at every step using the tools mentioned above. This study started with field practice from June 1, 2020, to March 31, 2021.

\subsection{Data Analysis}

The data obtained from the activities of the 10 stages were analyzed periodically by applying the concepts of Pongsapich (1983). The followings are the concepts used in this stage: (1) Categorize information into categories, (2) Actions or behaviors of people involved in the research, (3) Actions or behaviors that are a process with a continuous process, (4) Meaning is a description of a person's action or activity to know the worldview, beliefs, attitudes of the community, (5) Interpersonal relationships in the community involved, (6) Participation in activities, (7) ) Setting a picture of all aspects that can be recorded from the field of activities in all stages of research, (8) Organize data from textual recordings as descriptive events in all activities, and (9) Verification of the data analysis by the personnel involved and providing suggestions for improvement and completion. The quantitative analysis was descriptive statistics which were percentage, mean, and standard deviation. Inferential statistics were not used because participatory action research is context-specific research. It is not experimental research that requires research results from a sample to a population.

\section{Results}

The findings of the development of learning by e-learning system in Mahamakut Buddhist University, Mahavajiralongkorn Rajaviyalaya Campus were correlated with the study's objective as described in the following paragraphs.

\subsection{The Changes in the Identified Indicators Arising from the Development}

The evaluation forms were distributed to 21 lecturers and 40 students. The questions were 3 areas: 1) the program's application in the development of e-learning systems. 2) the use of the program to develop the Kammatthana Meditation learning by e-learning system, and 3) the enhancement of online media skills for teachers. The evaluations were conducted in 3 phases: pre-practice, post-practice in Cycle 1, and post-practice in Cycle 2. The results of each evaluation are shown in Table $1-3$ as follows.

3.1.1 The Findings in the Application of the Program in the Development of e-learning Systems Revealed that the Learning by E-Learning System was Improved. The Comparison Illustrated that the Pre-practice Mean was 1.94 While the Means of Post-practice in Cycle 1 and Cycle 2 were 2.63 and 4.10, Respectively, as Shown in Table 1. 
Table 1. Comparisons of Means of the Program Improvement between the Pre-practice and the Post-practice in Cycle 1 and Cycle 2

\begin{tabular}{|c|c|c|c|c|c|c|c|}
\hline \multirow[t]{2}{*}{ Item } & \multirow[t]{2}{*}{ Improvement indicators } & \multicolumn{2}{|c|}{ pre-practice } & \multicolumn{2}{|c|}{$\begin{array}{l}\text { post-practice } \\
\text { Cycle } 1\end{array}$} & \multicolumn{2}{|c|}{$\begin{array}{c}\text { post-practice } \\
\text { Cycle } 2\end{array}$} \\
\hline & & $\overline{\mathrm{X}}$ & S.D. & $\overline{\mathrm{X}}$ & S.D. & $\bar{X}$ & S.D. \\
\hline \multicolumn{8}{|c|}{ Content and Proceeding } \\
\hline 1. & The content is consistent with the learning purpose. & 1.80 & 0.64 & 3.00 & 0.58 & 4.00 & 1.00 \\
\hline 2. & Consistency of the amount of content in each unit & 2.20 & 0.53 & 2.80 & 0.53 & 4.00 & 0.58 \\
\hline 3. & Consistency in the hierarchy of content & 2.00 & 0.58 & 2.60 & 1.06 & 4.20 & 0.53 \\
\hline 4. & The correctness of the content & 2.20 & 0.64 & 2.40 & 0.50 & 4.40 & 0.35 \\
\hline 5. & Correspondence of the content with the learner level & 1.60 & 0.50 & 2.40 & 1.03 & 4.20 & 0.53 \\
\hline 6 & $\begin{array}{l}\text { Correspondence of the content with the pre and post-learning } \\
\text { exercises. }\end{array}$ & 1.80 & 0.53 & 2.40 & 0.50 & 4.00 & 0.58 \\
\hline \multicolumn{8}{|c|}{ Graphic and language use } \\
\hline 7. & Consistency between graphic and language & 1.80 & 0.53 & 2.60 & 0.50 & 4.00 & 0.58 \\
\hline 8. & Consistency between design and graphic frame & 2.00 & 0.58 & 2.80 & 0.53 & 4.00 & 0.58 \\
\hline 9. & Consistency between graphic and content & 1.80 & 0.53 & 2.80 & 0.53 & 4.20 & 0.53 \\
\hline \multicolumn{8}{|c|}{ Font and color } \\
\hline 10. & Consistency between font size and content & 1.60 & 0.50 & 2.80 & 0.53 & 4.00 & 0.58 \\
\hline \multicolumn{7}{|l|}{ Test } & 0.53 \\
\hline 12. & Consistency between test questions and objective & 1.60 & 0.50 & 2.60 & 0.50 & 4.20 & 0.64 \\
\hline 13. & Consistency between the number of questions and content & 2.20 & 0.53 & 2.60 & 0.50 & 4.20 & 0.64 \\
\hline \multirow[t]{2}{*}{14} & Consistency between the number of tests and content & 2.60 & 0.50 & 2.00 & 1.00 & 4.00 & 0.58 \\
\hline & Total & 1.94 & 0.15 & 2.63 & 0.55 & 4.10 & 0.20 \\
\hline
\end{tabular}

Note 1) Standard Deviation (SD) is low, indicating that the variance or dispersion of the respondents is not high.

The results showed improvement in Kammatthana Meditation learning by E-learning development, as can be seen in comparing the pre-practice evaluation mean (1.90) with the results of the post-practice evaluations of Cycle 1 (3.28) and Cycle 2 (4.22), respectively, as shown in Table 2.

Table 2. Comparisons of Means of Improvement in Kammatthana Meditation Learning by E-learning Development between the Pre-practice and the Post-practice in Cycle 1 and Cycle 2

\begin{tabular}{|c|c|c|c|c|c|c|c|}
\hline \multirow{2}{*}{$\begin{array}{l}\text { Ite } \\
\mathrm{m}\end{array}$} & \multirow[t]{2}{*}{ Improvement indicators } & \multicolumn{2}{|c|}{ pre-practice } & \multicolumn{2}{|c|}{$\begin{array}{c}\text { post-practice } \\
\text { Cycle } 1\end{array}$} & \multicolumn{2}{|c|}{$\begin{array}{c}\text { post-practice } \\
\text { Cycle } 2\end{array}$} \\
\hline & & $\bar{X}$ & S.D. & $\bar{X}$ & S.D. & $\bar{X}$ & S.D. \\
\hline \multicolumn{8}{|c|}{ Interesting lesson } \\
\hline 1. & Presentation method & 2.00 & 1.23 & 3.20 & 1.13 & 4.27 & 0.74 \\
\hline 2. & Lesson content & 1.83 & 1.02 & 3.17 & 1.09 & 4.13 & 0.78 \\
\hline 3. & Content order & 2.03 & 1.27 & 3.23 & 1.14 & 4.30 & 0.65 \\
\hline 4. & Proper content form & 1.93 & 1.11 & 3.63 & 0.93 & 4.17 & 0.87 \\
\hline \multicolumn{8}{|c|}{ User-friendliness } \\
\hline 5. & Introduction to the lesson & 1.97 & 1.22 & 3.47 & 1.01 & 4.23 & 0.73 \\
\hline 6. & Introduction to the lesson & 1.87 & 1.07 & 3.10 & 1.16 & 4.20 & 0.76 \\
\hline 7. & Pre-test and post-test & 1.97 & 1.07 & 3.23 & 1.14 & 4.17 & 0.87 \\
\hline 8. & Method for lesson information searching & 1.93 & 1.08 & 3.17 & 1.09 & 4.13 & 0.86 \\
\hline \multicolumn{8}{|c|}{ Content presentation } \\
\hline 9. & $\begin{array}{l}\text { Using the chart to present the topic of the lesson on the main menu and } \\
\text { sub-menu page. It helps students to see the relationship between the } \\
\text { learning orders in each topic. }\end{array}$ & 1.83 & 1.02 & 3.57 & 0.94 & 4.23 & 0.68 \\
\hline 10. & The amount of content presented for each channel is appropriate. & 1.87 & 1.11 & 3.10 & 1.18 & 4.13 & 0.90 \\
\hline 11. & The method of content presentation is easy to understand. & 1.93 & 1.05 & 3.17 & 1.05 & 4.17 & 0.83 \\
\hline
\end{tabular}




\begin{tabular}{|c|c|c|c|c|c|c|c|}
\hline \multicolumn{8}{|c|}{ Text font: size and color } \\
\hline 12. & Easy to understand & 1.83 & 0.99 & 3.33 & 1.06 & 4.23 & 0.63 \\
\hline 13. & Use words that convey meaning accurately and clearly. & 1.90 & 1.06 & 3.37 & 1.10 & 4.27 & 0.64 \\
\hline 14. & The font size is appropriate. & 1.93 & 1.08 & 3.50 & 1.04 & 4.30 & 0.65 \\
\hline 15. & The overall font color and the background & 1.87 & 1.07 & 3.30 & 1.06 & 4.17 & 0.75 \\
\hline 14. & The overall graphic color & 1.80 & 0.89 & 3.20 & 1.13 & 4.20 & 0.66 \\
\hline \multicolumn{8}{|c|}{ Illustration } \\
\hline 15. & The illustration is consistent with the content. & 1.83 & 0.91 & 3.30 & 1.06 & 4.23 & 0.63 \\
\hline 16. & The organization of illustration elements on each page is appropriate. & 1.87 & 1.07 & 3.23 & 1.14 & 4.33 & 0.61 \\
\hline 17. & The illustration clearness and size are appropriate. & 1.90 & 1.16 & 3.13 & 1.20 & 4.30 & 0.65 \\
\hline & The illustration is interesting & 1.87 & 1.07 & 3.23 & 1.14 & 4.27 & 0.64 \\
\hline & total & 1.90 & 1.01 & 3.28 & 0.84 & 4.22 & 0.63 \\
\hline
\end{tabular}

Note 1) Standard Deviation (SD) is low, indicating that the variance or dispersion of the respondents is not high.

The results showed improvement in the enhancement of online media skills for teachers, as can be seen in comparing the pre-practice evaluation mean (2.28) with the results of the post-practice evaluations of Cycle 1 (3.12) and Cycle 2 (4.34), respectively, as shown in Table 2.

Table 3. Comparisons of Means of Improvement in the Enhancement of Online Media Skills for Teachers between the Pre-practice and the Post-practice in Cycle 1 and Cycle 2

\begin{tabular}{|c|c|c|c|c|c|c|c|}
\hline \multirow[t]{2}{*}{ Item } & \multirow[t]{2}{*}{ Improvement indicators } & \multicolumn{2}{|c|}{ pre-practice } & \multicolumn{2}{|c|}{$\begin{array}{c}\text { post-practice } \\
\text { Cycle } 1\end{array}$} & \multicolumn{2}{|c|}{$\begin{array}{c}\text { post-practice } \\
\text { Cycle } 2\end{array}$} \\
\hline & & $\overline{\mathrm{X}}$ & S.D. & $\overline{\mathrm{X}}$ & S.D. & $\overline{\mathrm{X}}$ & S.D. \\
\hline 1. & Editing of course information & 2.00 & 1.31 & 2.87 & 1.25 & 4.25 & 0.62 \\
\hline 2. & Creating a structure of the subject content & 2.13 & 1.13 & 2.93 & 1.03 & 4.17 & 0.58 \\
\hline 3. & Inserting a week's schedule according to the course code & 2.33 & 1.18 & 3.13 & 0.92 & 4.58 & 0.51 \\
\hline 4. & Creating Page Content & 2.27 & 1.28 & 3.00 & 1.13 & 4.50 & 0.52 \\
\hline 5. & Inserting video from YouTube & 2.27 & 1.28 & 2.93 & 1.10 & 4.25 & 0.45 \\
\hline 6. & Creating a homework assignment & 2.53 & 1.30 & 3.53 & 1.30 & 4.42 & 0.51 \\
\hline 7. & Creating multiple-choice quizzes & 2.27 & 1.49 & 3.47 & 1.55 & 4.50 & 0.52 \\
\hline 8. & Creating a right, wrong answer, short answer, matching & 2.33 & 1.23 & 2.93 & 0.88 & 4.33 & 0.49 \\
\hline 9. & Creating content using Book & 2.27 & 1.10 & 2.93 & 0.88 & 4.25 & 0.45 \\
\hline 10. & Adding co-teachers and enable them to edit lessons & 2.33 & 1.23 & 2.93 & 1.10 & 4.42 & 0.67 \\
\hline 11. & Adding students to the system & 2.33 & 1.23 & 3.00 & 1.13 & 4.08 & 0.67 \\
\hline 12. & $\begin{array}{l}\text { Creating learning conditions. For example, students have to } \\
\text { accomplish } 70 \text { percent of the exam before learning the } \\
\text { following subjects. }\end{array}$ & 2.40 & 1.12 & 3.33 & 0.98 & 4.33 & 0.49 \\
\hline 13. & Score marking when students take a test and do homework & 2.53 & 1.13 & 3.60 & 0.99 & 4.33 & 0.49 \\
\hline 14. & Transferring the exam from a text file to Moodle & 2.13 & 1.25 & 3.20 & 1.15 & 4.25 & 0.62 \\
\hline 15. & Marking homework and examination, and exporting of scores & 2.07 & 1.10 & 3.07 & 1.16 & 4.42 & 0.51 \\
\hline & Total & 2.28 & 1.04 & 3.12 & 0.92 & 4.34 & 0.79 \\
\hline
\end{tabular}

Note 1) Standard Deviation (SD) is low, indicating that the variance or dispersion of the respondents is not high.

\subsection{Learning from Practice}

As a result of PAR's above principles, concepts, and practices, the researcher, research participants, and the campus gained active learning.

The researcher would like not to include details of each group mentioned in this research article because there were so many. However, he would like to bring together three crucial common learning issues that the researcher, the research participants, and the campus agreed upon to discuss. These issues were: 1) awareness of the importance of collaborative working, 2) awareness of the importance of being lifelong learners, and 3) awareness of the importance of reflection on the results of practice which was initially often neglected. 


\subsection{Body of Knowledge from Practice}

It was grounded theory knowledge, particularly in the context of learning by e-learning system in Mahamakut Buddhist University, Mahavajiralongkorn Rajaviyalaya Campus. It was not a body of reference knowledge that resulted from quantitative research. The overall results of lesson transcription and reflection revealed that this study created the body of knowledge from practice under Force-Field Analysis by Kurt Lewin. The components of Force-Field Analysis are Expected Change, Force for Change, Resistance to Change, and Overcome Obstacles. The relevant aspects of the analysis are discussed below.

- Expected Change. The expected changes were in the 3 indicators: 1) the program's application in the development of e-learning systems. 2) the use of the program to develop the Kammatthana Meditation learning by e-learning system, and 3) the enhancement of online media skills for teachers. (See the indicators for each program in tables 1-3 above)

- Force for Change. The researcher believed that the force resulted in the improvement in 3 areas as follows:

- Concepts for Development. The researcher and the research participants followed the following concepts to increase the efficiency of this research:1) Focus on change for learners; 2) Always pursue new ideas; 3) Focus on the convergence of theory and practice to create compelling work with a concrete and clear concept in each work process. It is like having eyes on both sides: appropriate theory and practice; 4) Aiming to inspire and achieve the full potential; 5) Focus on effective teamwork in collaboration between the researcher and the research participants; 6) Focus on leadership for change in everyone and encourage them to aim to change in the same direction; 7) Focus on creative leadership; 8) Focus on democracy to share different ideas from everyone's experience, and 9) Focus on sustainable development.

- Strategies for Development. The researcher used the strategies for development to provide a framework for the implementation of the development concept as follows: 1) Raise awareness that change takes time, patience, and continuity; 2) Encourage learning through practice in all activities and aim at everyone's benefit; - Empower the team to work powerfully, initiate and create differences in current work effectively

-Ways for Development There were 3 development programs used in this study.

1) A program to develop a 5-step e-learning system comprising (1) planning a project, (2) drafting a storyboard, (3) developing a curriculum, (4) reviewing a curriculum, and (5) delivering a curriculum

2) A program to develop Kammatthana Meditation learning by e-learning system comprising 9 steps (1) Needs Analysis, (2) Understanding the Content, (3) Learning Objectives, (4) Select Learning Strategy, (5) Create Outlines, (6) Prepare Detailed Content Outlines, (7) Create Teaching Storyboards, (8) Develop Curriculum Using Rapid Design Tool, and (9) Upload Curriculum on Technology Machine.

3) The program to enhance the online media skills for teachers consists of 5 steps (1) Set goals, (2) Develop design, (3) Create content, (4) Analyze, and (5) Increase efficiency.

- Resistance to Change. The resistances to change found in this study were: 1) some of the research participants were too old, had not much technology experience resulting in the lack of responsibility in participating with all one's afford, and 2) the media was not completely transferred to students resulting in the lack of interest to enter the system.

- Overcome Obstacles. The study found the following approaches. Firstly, provide continuous skill training in order to make everyone get used to the media. This suggestion may improve the existing force to be and for seeking a new, more powerful force. Secondly, adjust the original force and add better force to increase media use among the course instructors. Lastly, 3) Build more understanding of e-learning among the teachers to raise their awareness of the teaching profession, and pay more attention and responsibility in the course.

\section{Discussion}

The discussion was done in the following aspects.

\subsection{The Changes in the Identified Indicators Arising from the Development}

It was found that there were improvements in all indicators; 1) the application of the program in the development of e-learning systems, 2) the use of the program to develop the Kammatthana Meditation learning by e-learning system, and 3) the enhancement of online media skills for teachers. The comparison of changes is illustrated in the figure 1-3. (Note: the blue line indicates pre-evaluation, the pink line indicates post-operation in Cycle 1, and the yellow line indicates Cycle 2).) 


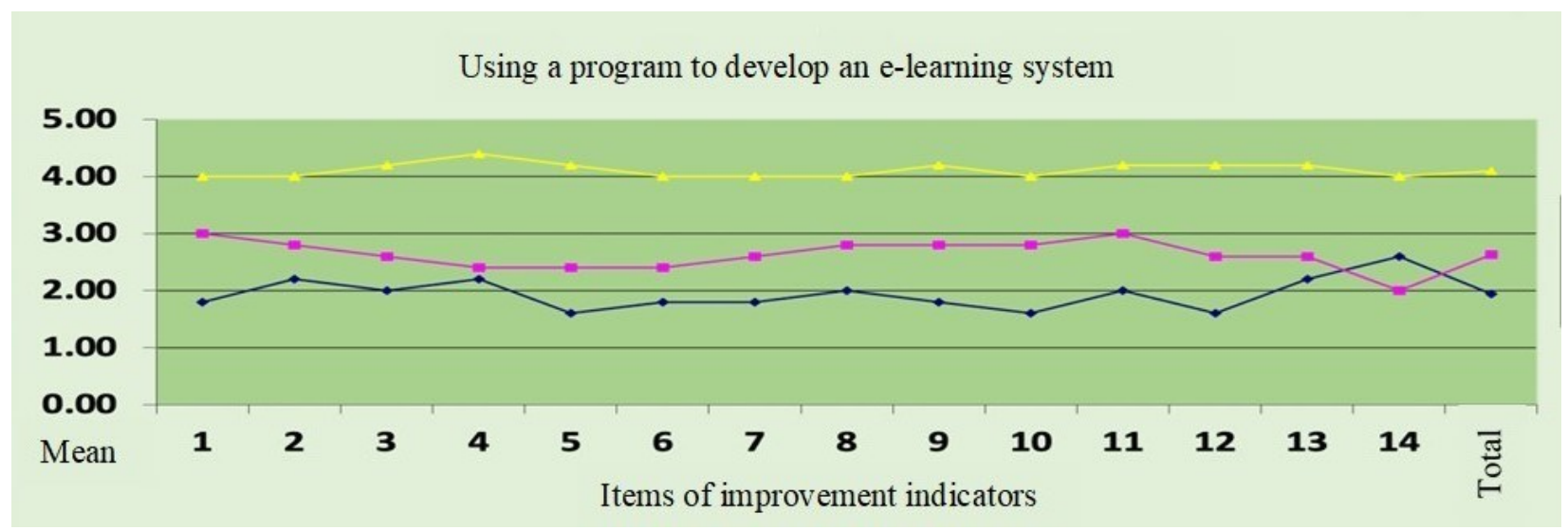

Figure 1. The Changes in the Identified Indicators Arising from the Development: The Program's Application in the Development of E-learning Systems

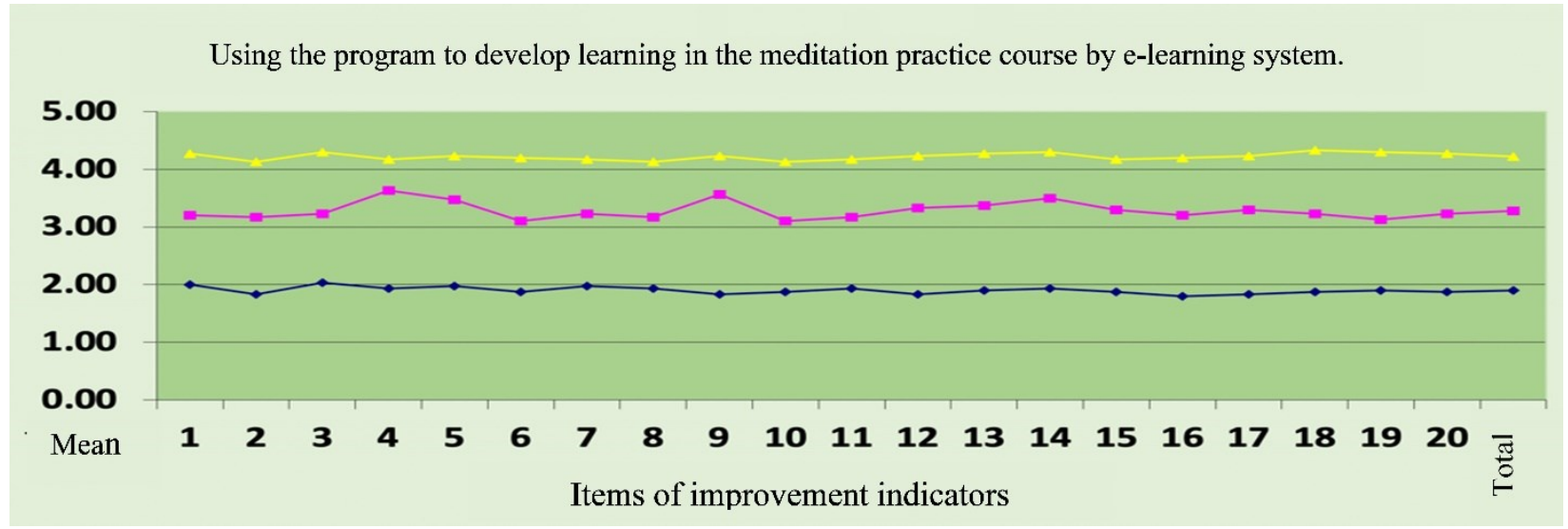

Figure 2. The Changes in the Identified Indicators Arising from the Development: The Use of the Program to Develop the Kammatthana Meditation Learning by E-learning System

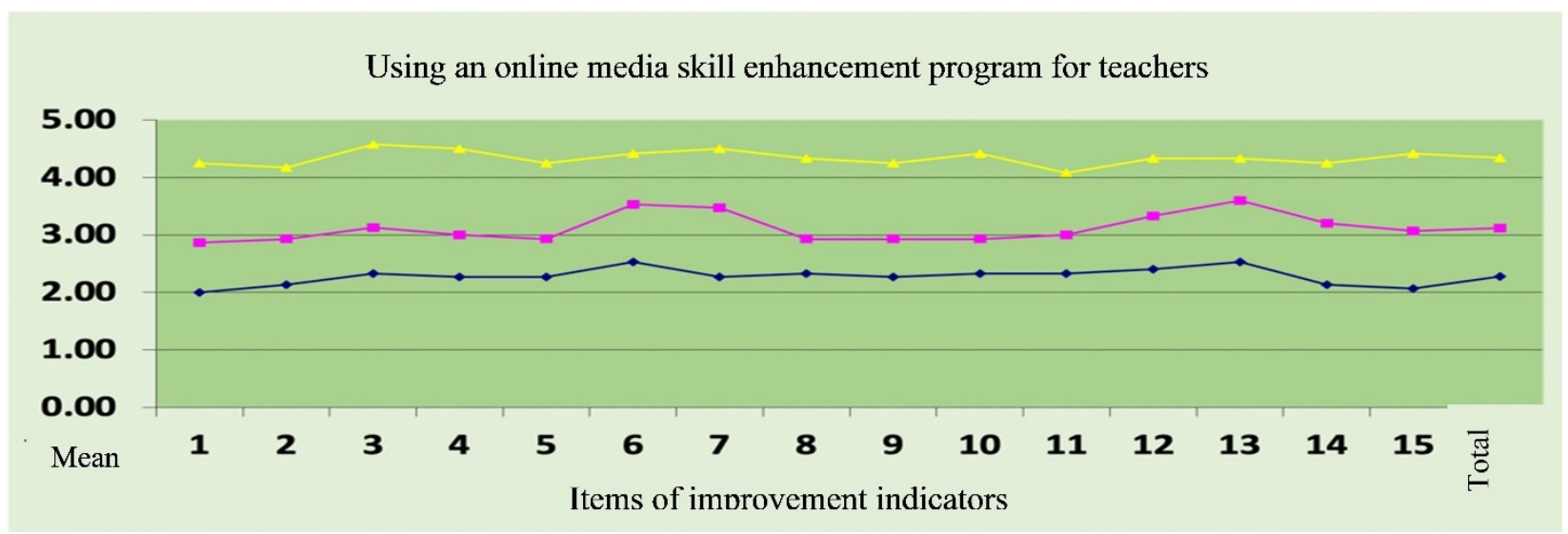

Figure 3. The Changes in the Identified Indicators Arising from the Development: The Enhancement of Online Media Skills for Teachers 
The researcher believed that the improved changes were due to the commitment to participatory action research's principles, concepts, and practices. The desired improvements were also caused by applying the aforementioned set of thoughts and beliefs in the knowledge gained from practice - the researcher was concerned with implementing leadership concepts, especially self-leaders and leaders for change. Moreover, the application of Buddhism doctrine was the critical element in working effectively.

The researcher focused on the self-leader concept because he believed in the theory that said, "Not everyone is born a leader, but anyone can become one" (TRISOFT team, 2019). Being a self-leader affects work efficiency. Fowler (2021) stated that "self-leaders are more likely to expend discretionary effort on behalf of their organizations, self-leaders are more likely to have positive feelings about their jobs, and self-leaders are more likely to perform at high levels, endorse their organization to others, remain with their organizations, and act as good organizational citizens. "In addition, if the self-leader has leadership for change, it will significantly affect the work efficiency because the leader for change has the skills critical to practical work. The mentioned skills are: foster innovation, act quickly, maintain strategic perspective, develop external perspective, and inspire and motivate. (Folkman, 2020)

The research applied Buddhism doctrine to enhance the work efficiency because Mahamakut Buddhist University, Mahavajiralongkorn Rajaviyalaya Campus, is a Buddhism University. The researcher, the research participants, and most of the students are monks. Therefore, they were familiar with the use of Buddhism doctrine in their work. The essential Buddhism teaching used in this operation was the path of accomplishment (4-iddhipada) which consists of 1) will; aspiration, (2) energy; effort, exertion, 3) thoughtfulness; active thought, and 4) investigation; examination; reasoning; testing. (Phra Thammapitaka (Prayut Payutto), 2003). Another Buddhism teaching used was the foursangghahavatthu which means the principles that happily bring the crowd, eliminate conflicts that arise, and make people coexist with love. The four-sangghahavatthu consists of 1) giving; generosity; charity2) kindly speech; persuasive speech, 3) proper conduct; rendering services; the life of service; doing good; and 4) even and equal treatment; behaving oneself properly (Sihong, 2016). This can be observed from the research participants, where they always advice each other that "Doing action research we don't just use our brains, but we have to work together with our hands. So, we need to unite, help each other, have patience, hold back, and persevere, in which we will success together."

\subsection{Learning from Practice}

The findings showed three important common learning issues that the researcher, the research participants, and the campus agreed upon to discuss, as follows: 1) awareness of the importance of collaborative working, 2) awareness of the importance of being lifelong learners, and 3) awareness of the importance of reflection on the results of practice which was initially often neglected. It reflected that this type of research could change the attitudes of the relevant parties in better directions. It was considered valuable learning because everyone can constantly apply the learning gained from this research in any future work to make it more effective (Kim, 2019).

First of all, everyone had an awareness of the importance of being involved in that work. It is said by the research participants that "In the past, we used to work independently. We don't often work together in groups. But when it comes to doing research that requires participation like this, it makes me feel good and shows the benefits that are better than before." Participation is a vital democracy practice, as Wynton Marsalis said: "We always hear about the rights of democracy, but the major responsibility of it is participation." Moreover, participation causes "everyone has the right to express their opinion freely" (The Election commission of Thailand, 2017).

Second, everyone had an awareness of the importance of being lifelong learners. It is said by the research participants that "We used to work from the habit of doing it. But after doing this research, it makes me realized that besides the usual experience we must learn new knowledge to develop our work as well." The PAR requires individuals who are lifelong learners in order to bring new lessons learned to initiate and create development more efficiently. The lifelong learners are the person who possesses the following qualities: developing a new skill, self-taught study, learning a new activity, learning to use new technology, and acquiring new knowledge (Valamis Group, 2019).

Lastly, everyone had an awareness of the importance of reflection on the results of the practice. As the research participants said, "We used to finish work and it's over. We never bring what has been done to discuss and analyze the strengths and weaknesses together." This is because the process of reflection helps us make sense of our day-to-day experiences, it can help us to move forward, to come to decisions, to create a course of action, to challenge ourselves to switch off autopilot and our habitual ways of doing and thinking (Liebenguth, 2018).

\subsection{Body of Knowledge Gained from Practice}

The findings illustrated that the body of knowledge gained from the operation was the set of thought consisting of 
Expected Change, Force for Change, Resistance to Change, and Overcome Obstacles. This set of thought was used, and it successfully improved the determined indicators. The body of knowledge gained from this PAR, particularly in the context of Mahamakut Buddhist University, Mahavajiralongkorn Rajaviyalaya Campus. It was not a body of reference knowledge that resulted from quantitative research that can be widely used in other universities. Instead, the grounded theory knowledge can be solely used in learning by e-learning system development in Mahamakut Buddhist University, Mahavajiralongkorn Rajaviyalaya Campus. However, other interested universities may analyze and apply it to suit their context. Coghlan \& Brannick (2007) and James, Milenkiewcz, \& Bucknam (2008) stated, “...despite its limited reference and publication, the ideas of participatory action research are applicable for different contexts to generate similar patterns of results...."

\section{Conclusion}

The findings in this study were in the particular context of Mahamakut Buddhist University, Mahavajiralongkorn Rajaviyalaya Campus. It was not a body of reference knowledge that resulted from quantitative research or experimental research. The overall results of lessons learned and reflection revealed that this study created the body of knowledge from the set of thought consisting of expected changes in identified indicators and implementation of force for change. It included Concepts for Development, Strategies for Development, and Ways for Development. The areas of the study covered the application of the program in the development of e-learning systems, the use of the program to develop the Kammatthana Meditation learning by e-learning system, and the enhancement of online media skills for teachers. The other vital components were the awareness of Resistance to Change and the awareness of Overcome Obstacles. Mahamakut Buddhist University, Mahavajiralongkorn Rajaviyalaya Campus still has to manage education endlessly, i.e., from one generation of students to another generation of students, or another academic year to another academic year. The operation continues, and the workload remains the same, but students will be the new faces every academic year. The Campus considers that the ideas and beliefs from this research are equated as valuable knowledge. It is a body of knowledge that will be used to raise the quality of learning by e-learning to a higher level. Furthermore, the Campus needs the pursuit of new ideas and beliefs to add every semester. In particular, in the prevalent COVID-19 pandemic, distance learning is greatly needed.

\section{References}

Aei, A. (2012, October 6). E-Learning. Management Frameworks. Retrieved from http://adisonx.blogspot.com/2012/10/e-learning.html

Alshehri, A., \& Cumming, T. M. (2020). Mobile technologies and knowledge management in higher education institutions: students' and educators' perspectives. World Journal of Education, 10(1), 1-11. https://doi.org/10.5430/wje.v10n1p12

Arhar, J. M., Holly, M. L., \& Kasten, W. C. (2001). Action research for teachers. New Jersey: Merrill Prentice Hall.

Banthitablog. (2017). Online instruction (e -learning). Banthita Blog. Retrieved from https://bit.ly/3bdKrjR

Carr, W., \& Kemmis, S. (1992). Becoming critical: Education, knowledge, and action research (3rd ed.). London: Falmer Press.

Casey, A. (2016, May 23). 7 Characteristics of learner-centered e-Learning. Corporate e-Learning. Retrieved from https://elearningindustry.com/7-characteristics-learner-centered-elearning

Chantasuriyawong. W. (1985). Some observations on the development of cooperative technology. Social Development Journal, 6, 49-57.

Charoenkong, I. (2014, December 8). Definition and importance of e-learning. e-Learning in the 21st Century. Retrieved from http://elearning-isaret.blogspot.com/2014/12/e-learning.html

Chawangpan, S. (n.d.). Design of e-learning instruction. e-Learning Group Report. Retrieved from https://sites.google.com/site/sirinartcwp/e-learning-design

Choojai, O. (2013, January 15). What is e-learning? e-Learning. Retrieved from http://06550149-02.blogspot.com/2013/01/e-learning.html

Coghlan, D., \& Brannick, T. (2007). Doing action research in your own organization (2nd ed.). Thousand Oaks, CA: Sage. 
Creswell, J. W. (2008). Educational research: Planning, conducting, and evaluating quantitative and qualitative research (3rd ed.). New Jersey: Merrill Prentice Hall.

Folkman, J. (2020, January 16). 5 Required skills for leading change. Forbes. Retrieved from https://www.forbes.com/sites/joefolkman/2020/01/16/5-required-skills-for-leading-change/?sh=39ec11b66a16

Fowler, S. (2021, June 3). The benefits of a self-leadership culture. Platinum Publishing Group. Retrieved from https://www.platinummediagroup.co.uk/surrey-chambers-of-commerce-magazine/2019/06/the-benefits-of-a-self -leadership-culture/

Hanımoğlu, E. (2018). The impact technology has had on high school education over the years. World Journal of Education, 8(6), 1-11. https://doi.org/10.5430/wje.v8n6p96

Insa-ard, S. (2018). E-Learning lesson design for developing higher thinking skills. Bangkok: V. Print.

James, E. A., Milenkiewicz, M. T., \& Bucknam, A. (2008). Participatory action research for educational leadership: Using data-driven decision making to improve schools. Thousand Oaks, CA: Sage.

Kaewthep, K. (1989). Community cultural development work: What it is and how to do it. Sangpattana Journal, (1-2), 14-35.

Kemmis, S., \& McTaggart, R. (1992). The action research planner (3rd ed.). Victoria: Deakin University.

Kim, M. (2019). Action research to overcome the stress caused by the combination of academic and work life of Korean early childhood education doctoral students. World Journal of Education, 9(5), 1-10. https://doi.org/10.5430/wje.v9n5p16

Laohajaratsang. T. (2008, July 5). Meaning of e-learning. e-Learning. Retrieved from https://www.kroobannok.com/1586

Liebenguth, K. (2018, June 5). Time to reflect - Why does it matter in the workplace? HR Zone. Retrieved from https://www.hrzone.com/perform/people/time-to-reflect-why-does-it-matter-in-the-workplace

Lunenburg, F. C., \& Ornstein, A. C. (2000). Educational administration: Concepts and practices (3rd ed.). Belmont, CA: Wadsworth Thomson Learning.

Mahamakut Buddhist University, Mahavajiralongkorn Rajaviyalaya Campus. (2019). Self-assessment report Course level Bachelor degree Undergraduate course standards. Bachelor of Education Program. Department of English Language Teaching, Academic Year 2019. (Copy)

McTaggart, R. (1991). Principles for participatory action research. Adult Education Quarterly, 41(3), 168-187. https://doi.org/10.1177/0001848191041003003

McTaggart, R. (2010). Participatory action research or change and development. Townsville, Australia: James Cook University.

Meejoe, J. (2015). Principles of e-learning. e-Learning Group Report. Retrieved from https://sites.google.com/site/meejoei8/e-learning7

Mills, G. E. (2007). Action research: A guide for the teacher researcher (3nd ed.). New Jersey: Merrill Prentice Hall.

Pahe, S. (2017). Educational media and technology (3rd ed.). Phrae: Phrae Thai Printing Industry Ltd., Part.

Petsringern, B. (2016, May 9). What is e-learning? e-Learning Online Lessons. Retrieved from https://bit.ly/2YyEQPZ

Phra Thammapitaka (Prayut Payutto) (2003). Ittibah 4. Buddhist Dictionary, Code of Dhamma (12th ed.). Retrieved from https://84000.org/tipitaka/dic/d_item.php?i=213

Pongsapich, A. (1983). Field research: Emphasis on observation. Bangkok: Faculty of Education, Chulalongkorn University.

Sakworawit, A. (2019, January 6). Thai university teachers used to be too comfortable backward until nowhere did not survive. Intelligence and Information. Retrieved from https://mgronline.com/daily/detail/9620000001757

Sanrattana, W. (2018). Educational administration research: Concepts and practices (4th digital ed.). Bangkok: Thipvisut.

Seanrin, N. (2013, January 3). Key characteristics of e-learning. e-Learning. Retrieved from http://eleaning-nitdaporn.blogspot.com/ 
Sihong, N. (2016, December 2). Sangkhahavatthu 4 and guidelines for working. Castool: Tooling System. Retrieved from https://bit.ly/3shEnMK

Sitthirit, C. (2015). e-Learning. $\quad$ Retrieved from https://sites.google.com/site/satawatkhom/1-khwam-hmay-khxng-e-learning

Supradit, P. (2015, October 19). What is e-learning? e-Learning. Retrieved from http://patipannongmakhua.blogspot.com/2015/10/e-learning.html

The Election commission of Thailand (2017, June 15). Roles of the Thai citizens in promoting and developing democracy, election and political public participation. Election Commission of Thailand. Retrieved from https://www.ect.go.th/ect_en/news_page.php?nid=1892\&filename $=$

TRISOFT team. (2019, February 13). Not everyone is born a leader, but anyone can become one. Every Idea Needs a Medium. Retrieved

from https://medium.com/remote-symfony-team/not-everyone-is-born-a-leader-but-anyone-can-become-one-8eb830 770223

Valamis Group (2019, April 8). Lifelong learning. Valamis. Retrieved from https://www.valamis.com/hub/lifelong-learning

\section{Copyrights}

Copyright for this article is retained by the author(s), with first publication rights granted to the journal.

This is an open-access article distributed under the terms and conditions of the Creative Commons Attribution license (http://creativecommons.org/licenses/by/4.0/). 